J. Gen. Appl. Microbiol.

Vol. 12, No. 3, 1966

\title{
EFFECT OF OXYGEN ON THE DEVELOPMENT OF RESPIRATORY ACTIVITY IN ESCHERICHIA COLI
}

\author{
SEIICHI HINO and MISUZU MAEDA \\ Botanical Institute, Faculty of Science, Hiroshima University, \\ Hiroshima, Japan \\ Received August 15, 1966
}

The fact that the respiratory activity of yeast cells can vary to a great extent depending on whether the cells were grown in the presence or absence of oxygen, was pointed out by WARBURG in 1927 (1). Subsequently, relationship between cytochrome composition and respiratory activity in yeast was shown by various workers. In 1950, EPHRUSSI and SLONIMSKI (2) reported that, when anaerobically grown yeast cells were aerated under conditions which precluded cell division, the respiratory activity rapidly increased, accompanied by the synthesis of several respiratory enzymes. Since then, many reports have appeared concerning the mechanism of the synthesis of these enzymes in this organism.

The idea that there is a relationship between the cytochrome composition and the degree of aerobiosis of bacteria was suggested by YAOI and TAMIYA in 1928 (3).

In contrast to numerous findings on yeast, information about the regulatory role of oxygen on the development of respiratory activity or on the content of respiratory enzymes in bacteria is still meager and even conflicting. For example, in Escherichia coli, Moss (4) reported that the respiratory activity of aerobically and anaerobically grown cells did not show marked difference, although the content of cytochromes $a_{2}$ and $b_{1}$ was distinctly higher in aerobic than in anaerobic cells. Moreover, ScHAEfFER (5) reported that the cytochrome content of $E$. coli did not differ significantly between aerobically and anaerobically grown cells.

In some other bacteria, the respiratory activity of aerobically grown cells was reported to be higher than that of anaerobically grown cells $(6-8)$. However, it is with only a few kinds of bacteria, e.g. Pasteurella pestis $(9,10)$, that the difference of respiratory activity was satisfactorily correlated with the change of respiratory enzymes. Apart from the development of respiratory activity, there are several reports that the content or composition of respiratory enzymes, particularly of cytochromes, was different between aerobically and anaerobically grown bacteria $(11,12)$. However, most of these studies were limited to a comparison of the change between separately grown cells, so that the possibility that the observed difference originated from the selective multiplication of a certain type of cells cannot be ruled out. 
In view of the recent progress in methodology in elucidating the regulatory mechanism of bacterial metabolism, reexamination of the effect of oxygen on the respiratory activity of $E$. coli was undertaken. It is expected that if any regulatory effect of oxygen were found on the formation of respiratory enzyme system in $E$. coli, there would be some difference in the underlying mechanism of the regulation between yeast and $E$. coli, because respiratory enzymes are localized in mitochondrial structure in yeast but not in $E$. coli.

\section{MATERIALS AND METHODS}

Organism and culture medium. Escherichia coli K12 (CAVALLI's Hfr strain, auxotrophic to methionine ${ }^{1}$ ) was used throughout the present study.

The culture medium was a glucose nutrient broth containing glucose $10 \mathrm{~g}$, Polypepton (Wako) $10 \mathrm{~g}$, concentrated beef extract (Kyokuto) $10 \mathrm{~g}$, and $\mathrm{NaCl} 1 \mathrm{~g}$ in $1,000 \mathrm{ml}$ of distilled water $(\mathrm{pH} 7.0)$. Glucose was eliminated from the medium when indicated.

Aerobically and anaerobically grown cells. Aerobically grown cells were obtained by growth in $20 \mathrm{ml}$ of the medium in 100-ml Erlenmeyer flasks aerating on a reciprocating shaker at 120 strokes per min with an amplitude of $6 \mathrm{~cm}$.

Preliminary experiments showed that respiratory activity of anaerobically grown cells did not differ significantly when cells were obtained by either shaking the cultures in pure nitrogen, or when culture fluids were filled to the narrow neck of flasks and incubated without shaking. The former method was used for the experiment to compare the respiratory activity of aerobically and anaerobically grown cells and the latter method for the rest of experiments.

Cells grown aerobically for about $24 \mathrm{hr}$ were added to fresh culture medium to make 0.1 to $0.2 \%$ inoculum and incubated aerobically or anaerobically for $18 \mathrm{hr}$ at $30^{\circ}$. Under anaerobic growth condition, cells underwent about eight cell divisions.

Aerobically grown cells were collected by centrifugation, washed twice with $0.02 \mathrm{M}$ phosphate buffer $(\mathrm{pH} 7.0)$ and suspended in the same buffer. Anaerobically grown cells were collected and washed in the same manner, and either used as such after suspending in the buffer or subjected to aeration.

Aeration of anaerobically grown cells. For aeration, anaerobic cells were resuspended in $10 \mathrm{ml}$ of an incubation mixture containing, unless otherwise indicated, $2 \%$ of vitamin-free casamino acids (Nissan) in $0.02 \mathrm{M}$ phosphate buffer $(\mathrm{pH} 7.0)$. The cell density in the suspension was made

1 The choice of methionine-less mutant had no special implication on the present experiment. The character was used only as an identifying marker for the isolation of respiratory-deficient mutants in experiments not included in this paper. 
several fold higher than the density level attained in the stationary growth phase of aerobic cultures in order to prevent cell division. The suspension was transferred to a $100-\mathrm{ml}$ Erlenmeyer flask and aerated on a shaker for $2.5 \mathrm{hr}$ at $30^{\circ}$. Cells were collected, washed twice, and suspended in the phosphate buffer.

As will be described later, respiratory activity of anaerobically grown cells increases by aeration. When the effect of various inhibitors on the development of respiratory activity was to be determined, respiration was measured before and after cells were aerated in casamino acid-buffer mixture containing various concentrations of the inhibitor. The increment of respiratory activity by aeration was thus obtained and percentage inhibition calculated as follows.

$$
\left(1-\frac{\text { Increment of activity in presence of inhibitor }}{\text { Increment of activity in absence of inhibitor }}\right) \times 100
$$

Measurement of respiratory activity. Oxygen uptake was measured by the conventional manometric technique at $30^{\circ}$. After temperature equilibrium, $0.2 \mathrm{ml}$ of $0.1 \mathrm{M}$ substrate was added from the side arm to the main chamber containing $0.6 \mathrm{ml}$ of $0.1 \mathrm{M}$ phosphate buffer $(\mathrm{pH} 7.0), 1.0 \mathrm{ml}$ of cell suspension, and $0.2 \mathrm{ml}$ of water. Respiratory activities were expressed as $\mathrm{Q}_{2}(\mathrm{~N})$. Endogenous respiration, the $\mathrm{Q}_{2}(\mathrm{~N})$ value of which was generally below 10, was subtracted in most of experiments reported in this paper. The amount of cell nitrogen per flask was between 0.1 and $0.3 \mathrm{mg}$.

Cytochrome spectra. Cytochrome spectra of intact cell suspensions were measured with a Shimadzu recording spectrophotometer model MPS-50. Three milliliter each of the suspension was added to a cuvette of $10 \mathrm{~mm}$ light path. Absolute reduced or reduced minus oxidized difference spectra were recorded after cytochromes were reduced with $0.4 \mathrm{ml}$ of $0.1 \mathrm{M}$ soidum ascorbate and a few grains of dithionite, or oxidized with $0.4 \mathrm{ml}$ of $0.33 \mathrm{M}$ potassium ferricyanide.

Determination of cell nitrogen and analysis of glucose. In most of the experiments reported in this paper, the amount of cell nitrogen was directly analyzed by the Kjeldahl method. In some of the experiments when the absolute value of $\mathrm{QO}_{2}(\mathrm{~N})$ was not critically needed, cell nitrogen was calculated from the linear portion of a standard curve for turbidity and the amount of nitrogen per $\mathrm{ml}$ of the cell suspension. The turbidity of cell suspensions in $18-\mathrm{mm}$ test tubes was determined by a Hitachi EPO-B photometer using a 660-m $\mu$ filter and expressed by absorbancy.

Glucose was analyzed by the colorimetric method of PARK and JOHNSON (13).

\section{RESULTS}

Respiratory activity of aerobically and anaerobically grown cells

Respiratory activity of $E$. coli cells, grown either aerobically or anaero- 
Table 1. Respiratory activity of cells grown aerobically and anaerobically in glucose nutrient broth.

\begin{tabular}{lrc|r} 
& \multicolumn{2}{c|}{$\mathrm{QO}_{2}(\mathrm{~N})$} & \multicolumn{1}{c}{$(\mathrm{A})$} \\
\cline { 2 - 3 } Substrate & $\begin{array}{c}\text { Aerobic } \\
\text { cells (A) }\end{array}$ & $\begin{array}{c}\text { Anaerobic } \\
\text { cells }(\mathrm{B})\end{array}$ & $(\mathrm{B})$ \\
\hline Glucose & 950 & 530 & 1.8 \\
Lactate & 290 & 160 & 1.8 \\
Pyruvate & 660 & 280 & 2.4 \\
Formate & 1900 & 350 & 5.4 \\
Malate & 47 & 7 & 6.7 \\
Succinate & 230 & 23 & 10.0 \\
Acetate & 75 & 5 & 15.0
\end{tabular}

Cells were grown by shake culture in air or in nitrogen using nutrient broth containing $1 \%$ glucose.

bically in glucose nutrient broth was measured using seven different substrates. The result listed in Table 1 shows that there was a general tendency for aerobic cells to have higher respiratory activity than anaerobic cells, irrespective of the substrate employed. Although the difference in respiratory activity between the two types of cells was less pronounced when glucose, lactate, or pyruvate was used as a substrate, the activity of aerobic cells on formate, succinate, acetate, or malate being between 6 and 15 times larger than that of anaerobic cells.

Effect of oxygen on the increase of respiratory activity of anaerobically grown cells

The above result shows that when a suitable substrate is chosen, it is possible to obtain distinct difference in respiratory activity between aerobically and anaerobically grown cells. An attempt was therefore made to increase the respiratory activity of anaerobically grown $E$. coli by aerating the cells in the absence of cell proliferation. Aeration of the anaerobic cells in glucose-containing buffer, a procedure which was successful in increasing the respiratory activity of anaerobically grown yeast (2), did not significantly increase the activity. Aeration of the dense suspension of anaerobic cells in fresh glucose nutrient broth was also unsuccessful. It was later found that respiratory activity of anaerobic cells rapidly increased if cells were aerated in a glucose-free nutrient broth or in a buffer containing amino acids.

It is shown in Fig. 1 that if a dense cell suspension of anaerobically grown $E$. coli was aerated in phosphate buffer containing $2 \%$ casamino acids (vitamin-free) for $1 \mathrm{hr}, \mathrm{Q}_{2}(\mathrm{~N})$ value for succinate increased from an initial value of about 40 to about 500. The same graph also shows that if 


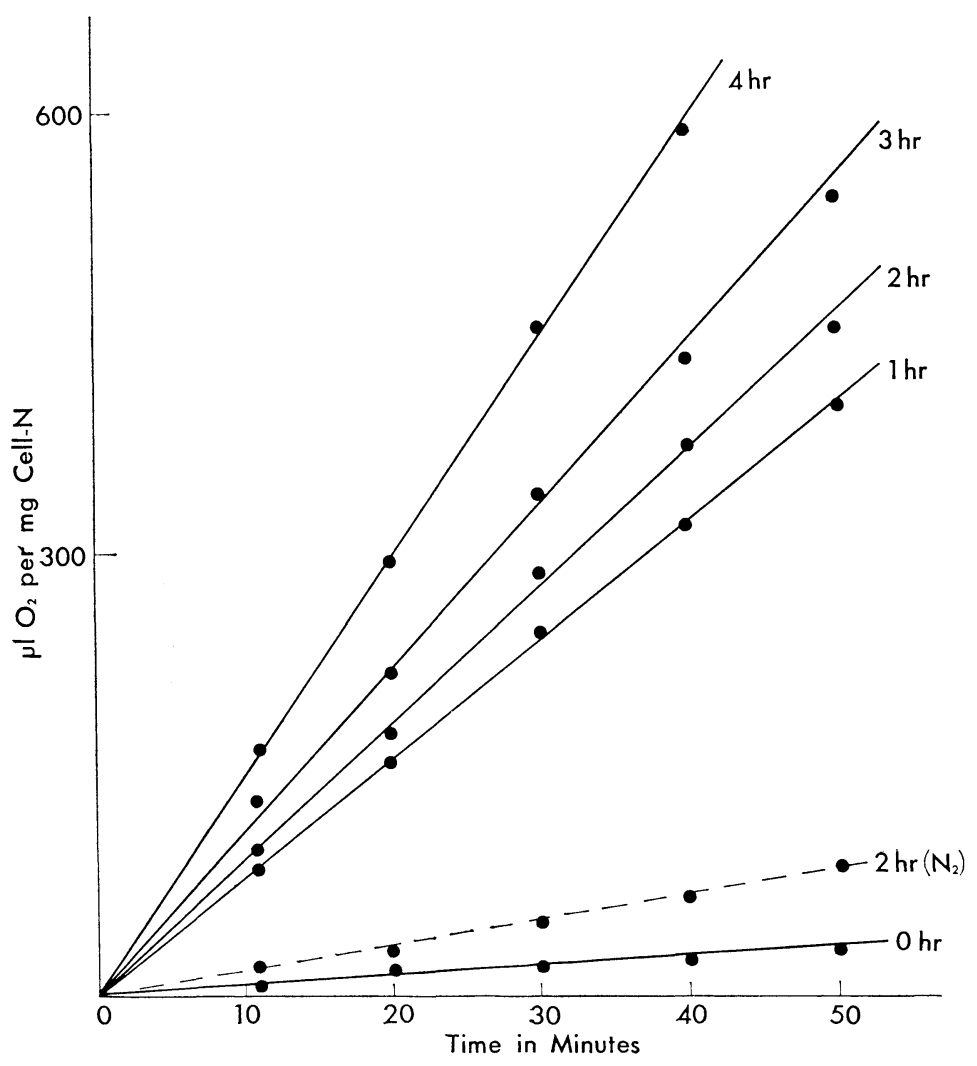

Fig. 1. Respiratory activity of anaerobically grown $E$. coli before and after aeration.

Washed suspensions of anaerobically grown cells were added to a buffer containing 2\% casamino acids and shaken in air for 1 to $4 \mathrm{hr}$ or shaken in nitrogen for $2 \mathrm{hr}$. Cells were recovered and respiratory activity measured using succinate as a substrate. Endogenous respiration subtracted.

the suspension was shaken in nitrogen, there was only a slight increase of the respiratory activity during $2 \mathrm{hr}$.

In the above experiments, cells were present to make dense enough suspension to prevent cell proliferation during the aeration. In Table 2, results of the measurement of turbidity of cell suspension, direct cell count, and the determination of cell nitrogen before and after aeration are listed. The change of respiratory activity in five kinds of substrate is also shown in the same table. These results demonstrate that respiratory activity of 
Table 2. Respiratory activity and amount of cells before and after aeration.

\begin{tabular}{l|c|c|c}
\hline \multicolumn{2}{c}{} & $0 \mathrm{hr}$ & $2.5 \mathrm{hr}$ \\
\hline & Glucose & 420 & 370 \\
$\mathrm{QO}_{2}(\mathrm{~N})$ & Lactate & 60 & 310 \\
& Succinate & 28 & 410 \\
& Malate & 0 & 290 \\
& Acetate & 0 & 150 \\
\hline Turbidity $(1 / 10)$ & 0.140 & 0.138 \\
Cell/ml & $4.0 \times 10^{9}$ & $4.2 \times 10^{9}$ \\
Cell-N/ml (mg) & 0.244 & 0.244 \\
\hline
\end{tabular}

Anaerobically grown cells were washed, suspended in a buffer containing $2 \%$ casamino acids, and shaken in air for 2.5 $\mathrm{hr}$. Before $(0 \mathrm{hr})$ and after $(2.5 \mathrm{hr})$ aeration, aliquots of the suspension were analyzed for turbidity (using 1:10 dilution), total cell count, cell nitrogen, and respiratory activity. For the latter two determinations, suspension was centrifuged, cells were washed, and resuspended in a definite volume of buffer. Endogenous respiration was subtracted.

anaerobically grown $E$. coli increased in several substrates by aeration, without accompanying significant cell multiplication. That the newly divided cells, if any, gave insignificant contribution to the increase of respiratory activity was confirmed by the fact that addition of 500 units of penicillin per $\mathrm{ml}$ of the cell suspension during aeration did not decrease the development of the respiratory activity.

\section{Effect of other factors on the increase of respiratory activity}

Amino acids. To develop the respiratory activity of anaerobically grown cells, buffer solution was generally supplemented with casamino acids, elimination of which resulted in complete loss of the development. In order to find out the amino acid requirement of the process, casamino acids were first replaced by a mixture of 18 amino acids, mixed in proportion to the composition of these amino acids in casein, then one amino acid was eliminated from the mixture, one at a time. Its result revealed that seven amino acids_-valine, leucine, isoleucine, serine, threonine, aspartate, and glutamate-were required. In Table 3 is shown that the mixture of eight amino acids (methionine was added to the seven amino acids because the organism is auxotrophic to this amino acid) is almost as effective as casamino acids, and also that elimination of any one of the above seven amino acids resulted in decreased stimulation of the respiratory activity.

Inhibitors of protein synthesis. Although the organism is auxotrophic 
Table 3. Effect of amino acids on the development of respiratory activity.

\begin{tabular}{|c|c|c|}
\hline \multirow{2}{*}{ Amino acids } & \multicolumn{2}{|c|}{$\mathrm{QO}_{2}(\mathrm{~N})$ after aeration } \\
\hline & Expt. 1 & Expt. 2 \\
\hline Casamino $\operatorname{acids}^{a}$ & 420 & 630 \\
\hline 8 Amino acids $^{b}$ & 420 & 450 \\
\hline 8 Amino acids - leucine & 350 & 400 \\
\hline 8 Amino acids - isoleucine & 140 & 150 \\
\hline 8 Amino acids - valine & 180 & 250 \\
\hline 8 Amino acids - serine & 90 & 70 \\
\hline 8 Amino acids - threonine & 410 & 370 \\
\hline 8 Amino acids - aspartate & 200 & 200 \\
\hline 8 Amino acids - glutamate & 250 & 280 \\
\hline
\end{tabular}

Anaerobically grown cells were aerated for $2.5 \mathrm{hr}$ in phosphate buffer containing amino acid mixture as indicated above. Cells were washed and respiratory activity measured on succinate. $\mathrm{QO}_{2}(\mathrm{~N})$ before aeration was about 40 . Endogenous respiration is included.

a Concentration of casamino acids was $2 \%$.

$b \quad$ L-Leucine, $16 \mathrm{mg}$; DL-isoleucine, $12.5 \mathrm{mg}$; DL-valine, $12.5 \mathrm{mg}$; DL-serine, $12.5 \mathrm{mg}$; DL-threonine, $9.5 \mathrm{mg}$; L-aspartic acid, $17 \mathrm{mg}$; sodium L-glutamate, $45 \mathrm{mg}$; and DL-methionine, $5 \mathrm{mg}$ per $10 \mathrm{ml}$ of the buffer.

Table 4. Effect of amino acid analogs on the development of respiratory activity.

\begin{tabular}{l|c}
\multicolumn{1}{c|}{ Cells } & $\mathrm{QO}_{2}(\mathrm{~N})$ \\
\hline Unaerated & 15 \\
Aerated with 8 amino acids & 330 \\
Aerated with 8 amino acids - methionine & 320 \\
Aerated with 8 amino acids +ethionine & 340 \\
Aerated with 8 amino acids +ethionine-methionine & 160 \\
\hline Unaerated & 33 \\
Aerated with 8 amino acids & 560 \\
Aerated with 8 amino acids +fluorophenylalanine & 120 \\
Aerated with 8 amino acids +fluorophenylalanine & 590 \\
& \\
\hline
\end{tabular}

For composition of 8 amino acids, see legend under Table 3. Concentrations of amino acids and analogs were: DL-methionine, $5 \mathrm{mg}$; DL-ethionine, $15 \mathrm{mg}$; L-phenylalanine, $2.4 \mathrm{mg}$; and DL-p-fluorophenylalanine, $2.6 \mathrm{mg}$ per $10 \mathrm{ml}$. Respiration was measured using succinate as a substrate. Endogenous respiration is included. 


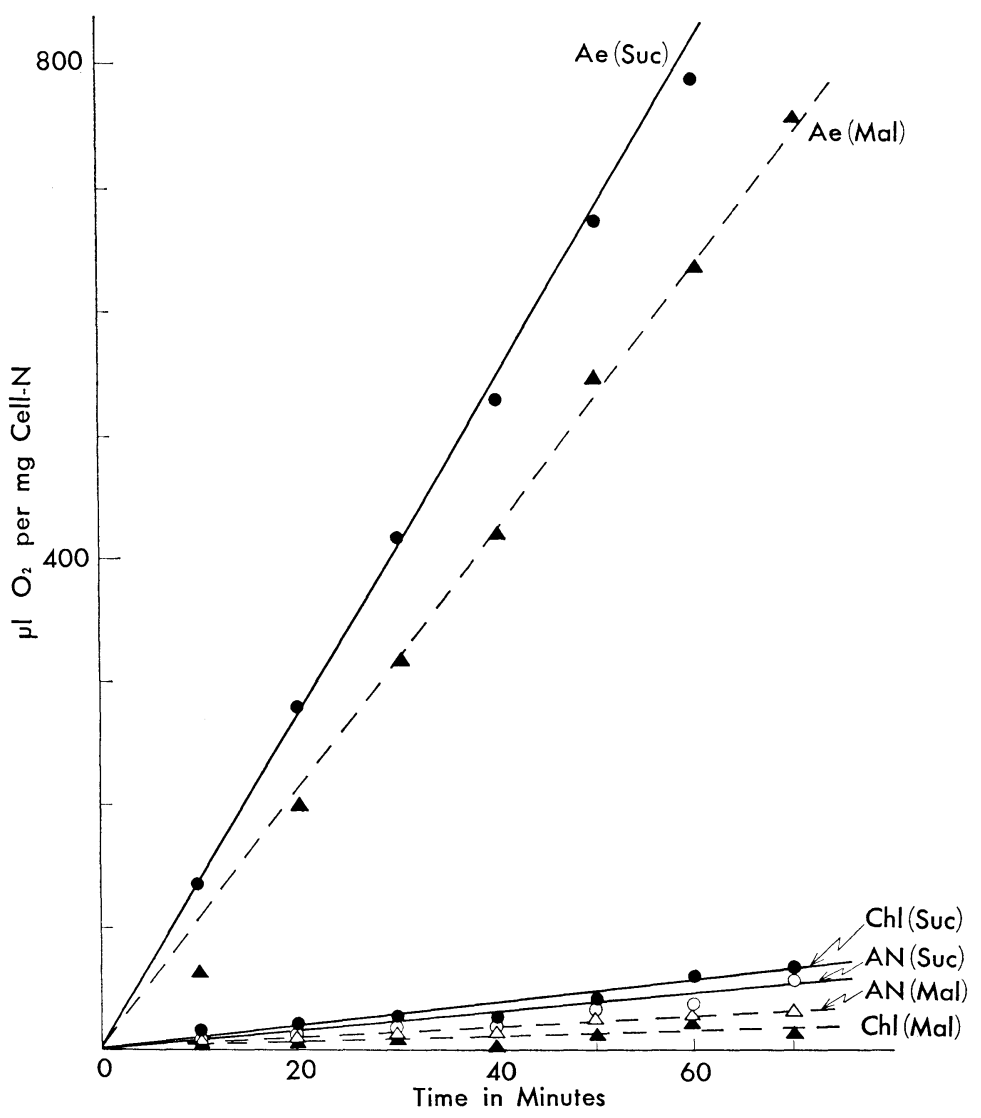

Fig. 2. Effect of chloramphenicol on the development of respiratory activity.

Anaerobically grown cells were aerated in a buffer containing casamino acids, in the presence or absence of $60 \mu \mathrm{g} / \mathrm{ml}$ of chloramphenicol. Respiratory activity was measured using cells unaerated $(\mathrm{AN})$, and aerated in the absence (Ae) or in the presence (Chl) of chloramphenicol. Succinate (solid line) and malate (broken line) were used as substrates of respiration. Endogenous respiration subtracted.

to methionine, elimination of this amino acid from the aerating mixture generally did not influence the development of respiratory activity. When ethionine was added in the absence of methionine, there was a definite inhibition, which could be reversed by the addition of methionine (Table 4). $p$-Fluorophenylalanine was also inhibitory and the effect was reversed by phenylalanine (Table 4).

Chloramphenicol, when added to casamino acid buffer solution in a 
Table 5. Effect of inhibitors on respiration and development of respiratory activity.

\begin{tabular}{|c|c|c|c|}
\hline \multirow{2}{*}{ Inhibitor } & \multirow{2}{*}{$\begin{array}{l}\text { Concentration } \\
\text { (M except CO) }\end{array}$} & \multicolumn{2}{|c|}{ Inhibition $^{a}(\%)$} \\
\hline & & Respiration & $\begin{array}{l}\text { Development } \\
\text { of respiration }\end{array}$ \\
\hline CO (dark) & $95 \%{ }^{b}$ & 34 & 77 \\
\hline CO (light) & $95 \%{ }^{b}$ & 34 & 75 \\
\hline \multirow[t]{3}{*}{$\mathrm{KCN}$} & $10^{-3.0}$ & 97 & 91 \\
\hline & $10^{-3.5}$ & 86 & 79 \\
\hline & $10^{-4.0}$ & 52 & 64 \\
\hline \multirow[t]{4}{*}{$\mathrm{NaN}_{3}$} & $10^{-2.5}$ & 87 & 73 \\
\hline & $10^{-3.0}$ & 65 & 58 \\
\hline & $10^{-3.5}$ & 51 & 37 \\
\hline & $10^{-4.0}$ & 21 & 5 \\
\hline \multirow[t]{4}{*}{ Amytal } & $10^{-2.5}$ & 62 & 100 \\
\hline & $10^{-3.0}$ & 24 & 86 \\
\hline & $10^{-3.5}$ & 6 & 51 \\
\hline & $10^{-4.0}$ & 0 & 14 \\
\hline \multirow[t]{3}{*}{ 2, 4-Dinitrophenol } & $10^{-3.5}$ & 92 & 90 \\
\hline & $10^{-4.0}$ & 21 & 47 \\
\hline & $10^{-4.5}$ & 0 & 0 \\
\hline \multirow[t]{2}{*}{$p$-Nitrophenol } & $10^{-3.5}$ & 94 & 100 \\
\hline & $10^{-4.0}$ & 0 & 18 \\
\hline \multirow[t]{4}{*}{ Monoiodoacetate } & $10^{-2.5}$ & 65 & 98 \\
\hline & $10^{-3.0}$ & 50 & 95 \\
\hline & $10^{-3.5}$ & 30 & 92 \\
\hline & $10^{-4.0}$ & 14 & 29 \\
\hline
\end{tabular}

a Percentage inhibition of the development of respiration was calculated as shown in "MATERIALS AND Methods".

b $95 \% \mathrm{CO}+5 \% \mathrm{O}_{2} ; 95 \% \mathrm{~N}_{2}+5 \% \mathrm{O}_{2}$ in control.

Substrate for respiration is succinate.

concentration of $60 \mu \mathrm{g} / \mathrm{ml}$, completely inhibited the development of respiratory activity by aeration (Fig. 2).

Inhibitors of respiration. Because oxygen is obligatorily needed for the development of respiratory activity in anaerobically grown cells, examination was made to see whether oxygen serves merely as the terminal acceptor of electron transport or is more directly concerned in the develop- 


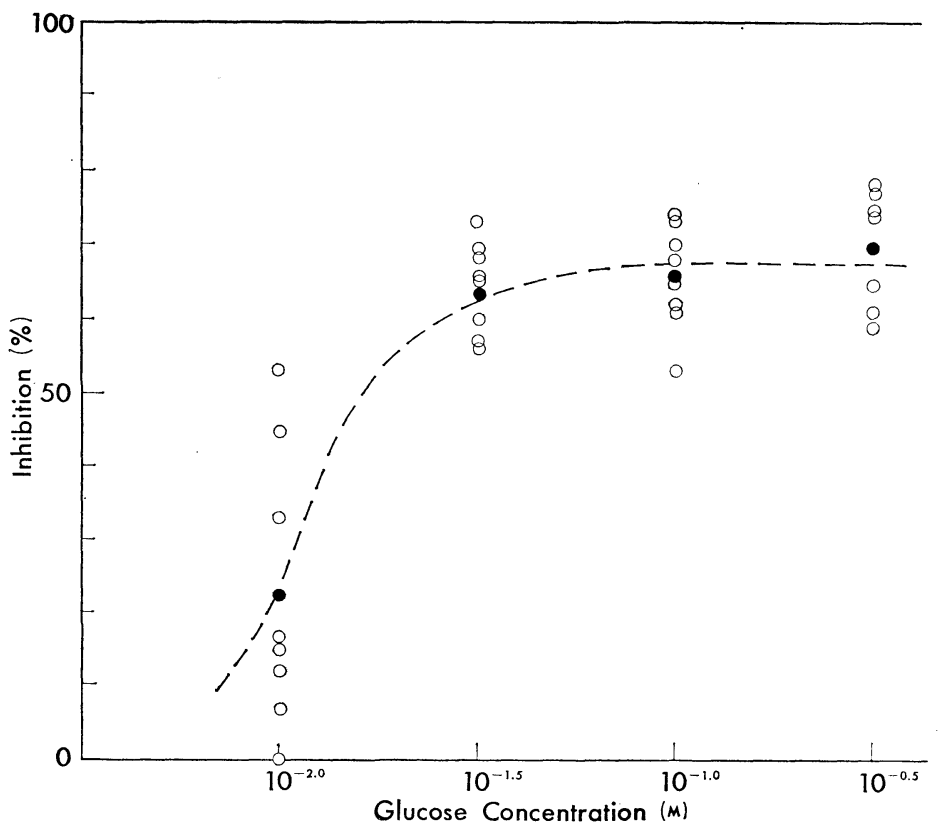

Fig. 3. Effect of glucose on the development of respiratory activity by aeration.

Anaerobically grown cells were aerated in incubation mixtures (buffer plus casamino acids) containing various initial concentrations of glucose. After $2.5 \mathrm{hr}$, cells were recovered and respiration measured on succinate. Percentage inhibition of the development of respiratory activity is calculated as has been described in "Materials and Methods". Solid circles and open circles represent mean value and each value respectively of percentage inhibition obtained by several independent experiments.

ment of respiratory activity, for example as an inducer of respiratory enzyme formation. In yeast it was reported (14) that development of respiration by oxygen proceeds under condition in which cyanide completely inhibits respiration.

In the present study, the effects of malonate, fluoride, monoiodoacetate, 2,4-dinitrophenol, $p$-nitrophenol, azide, cyanide and carbon monoxide were examined both on respiration of aerobic cells (substrate; succinate) and on the development of respiratory activity (in the presence of casamino acids) in anaerobic cells. The effect of carbon monoxide was studied by shaking cells in either gas mixture of $95 \% \mathrm{CO}$ and $5 \% \mathrm{O}_{2}$ or a mixture of $95 \% \mathrm{~N}_{2}$ and $5 \% \mathrm{O}_{2}$. To examine the effect of light on $\mathrm{CO}$ inhibition, cells were illuminated by a $20-\mathrm{w}$ fluorescent lamp from a distance of $20 \mathrm{~cm}$ (ca. 3,000 
lux); the light was intense enough to reverse completely the CO inhibition of respiration by yeast cells.

This result is shown in Table 5. The effects of malonate and fluoride are not included in the table, since these inhibit neither respiration nor the development of respiration. Although data are not listed in the table, percentage inhibition by various poisons on respiration of aerobic cells was almost identical whether the respiratory substrate was succinate or casamino acids. As may be seen from the table, inhibitory effects of various poisons are very similar on both respiration and on the development of respiratory activity, though monoiodoacetate and Amytal are slightly more toxic for the development of respiration than for respiration. No substance is significantly more toxic to respiration, so that it was not possible to find out the condition under which development of respiratory activity takes place in virtual absence of respiration.

Glucose. The development of respiratory activity by aeration in resting cells of anaerobically grown $E$. coli is inhibited by glucose. The result of several experiments on the effect of glucose is summarized in Fig. 3. As is shown in this graph, percentage inhibition at a concentration of $10^{-2.0} \mathrm{M}$ was variable in series of experiments. The fluctuation of inhibition suggested the possibility that a low amount of glucose is consumed by cells during aeration and the time required for the consumption is different between separate experiments.

It appeared desirable to determine the actual concentration of glucose before and after aeration. One of such determinations is listed in Table 6 . It is shown that glucose concentration remained practically unchanged, if the initial concentration was higher than $10^{-1.5} \mathrm{M}$. It is also shown that glucose at initial concentration of $10^{-2.0} \mathrm{M}$ was almost completely consumed during the aeration; it appears that, if glucose were kept at this initial concentration, inhibition should be greater than the apparent level. Again referring to Fig. 3, it is clear that in spite of ten-fold difference in glucose concentration, the inhibition remains at an almost constant level of 60 to $70 \%$.

In experiments so far described, $E$. coli was grown, aerobically or anaerobically, in nutrient broth containing glucose. Because glucose was found to be inhibitory to the development of the respiratory activity, the activity of cells grown in a medium deprived of glucose was determined. The result with such cells, grown either aerobically or anaerobically, shows (Table 7 ) that generally the respiratory activity is higher, sometimes remarkably higher, than the activity of cells grown in the presence of glucose. Even with cells grown in the absence of glucose, the tendency is still apparent that aerobically grown cells have higher respiratory activity than anaerobically grown cells. The cells anaerobically grown in glucose-free medium, when aerated in a buffer containing casamino acids, also showed increase in their respiratory activity (Fig. 4). 
Table 6. Concentration of glucose before and after aeration.

\begin{tabular}{|c|c|c|c|}
\hline \multirow{2}{*}{ Cell suspension } & \multirow{2}{*}{$\mathrm{QO}_{2}(\mathrm{~N})$} & \multicolumn{2}{|c|}{$\begin{array}{l}\text { Glucose concentration } \\
\text { found }(\mathrm{mg} / \mathrm{ml})\end{array}$} \\
\hline & & at $0 \mathrm{hr}$ & at $2.5 \mathrm{hr}$ \\
\hline Unaerated $(0 \mathrm{hr})$ & 25 & & \\
\hline Aerated without glucose & 520 & & \\
\hline Aerated with $10^{-2.0} \mathrm{M}$ glucose & 350 & 1.45 & 0.00 \\
\hline Aerated with $10^{-1.5} \mathrm{M}$ glucose & 200 & 6.10 & 4.20 \\
\hline Aerated with $10^{-1.0} \mathrm{M}$ glucose & 170 & 17.4 & 15.0 \\
\hline Aerated with $10^{-0.5} \mathrm{M}$ glucose & 150 & 57.0 & 54.0 \\
\hline Shaken in $\mathrm{N}_{2}$ without glucose & 60 & & \\
\hline
\end{tabular}

Anaerobically grown cells were suspended in a buffer containing $2 \%$ casamino acids in the presence or absence of various concentrations of glucose. The suspensions were shaken in air or nitrogen for $2.5 \mathrm{hr}$, cells were collected, and respiration measured on succinate. $\mathrm{In}_{\mathrm{QO}_{2}}(\mathrm{~N})$, endogenous respiration was subtracted. In glucose-containing series, an aliquot of suspensions was removed before and after aeration, centrifuged, and glucose concentration was determined after suitable dilution of the supernatant.

Table 7. Respiratory activity of cells grown aerobically or anaerobically in nutrient broth.

\begin{tabular}{l|c|c|c} 
& \multicolumn{2}{|c|}{$\mathrm{QO}_{2}(\mathrm{~N})$} & \\
Substrate & $\begin{array}{c}\text { Aerobic } \\
\text { cells (A) }\end{array}$ & $\begin{array}{c}\text { Anaerobic } \\
\text { cells (B) }\end{array}$ & (B) \\
\hline Glucose & 390 & 380 & 1.0 \\
Lactate & 1030 & 320 & 3.2 \\
Malate & 330 & 83 & 4.0 \\
Succinate & 840 & 230 & 3.7 \\
Acetate & 660 & 140 & 4.7 \\
\hline
\end{tabular}

Cells were grown by shake culture in air or nitrogen using nutrient broth.

\section{Cytochrome spectra of aerobically and anaerobically grown cells}

The absolute reduced spectra (Fig. 5) and reduced minus oxidized difference spectra (Fig. 6) were measured using suspensions of cells grown aerobically and anaerobically, and cells aerated in the absence of cell division. In measuring these spectra, cell concentrations in the suspensions were adjusted to be almost identical. The reduced spectra of cells grown aerobically in media without glucose (Curve A in Fig. 5) and with glucose 


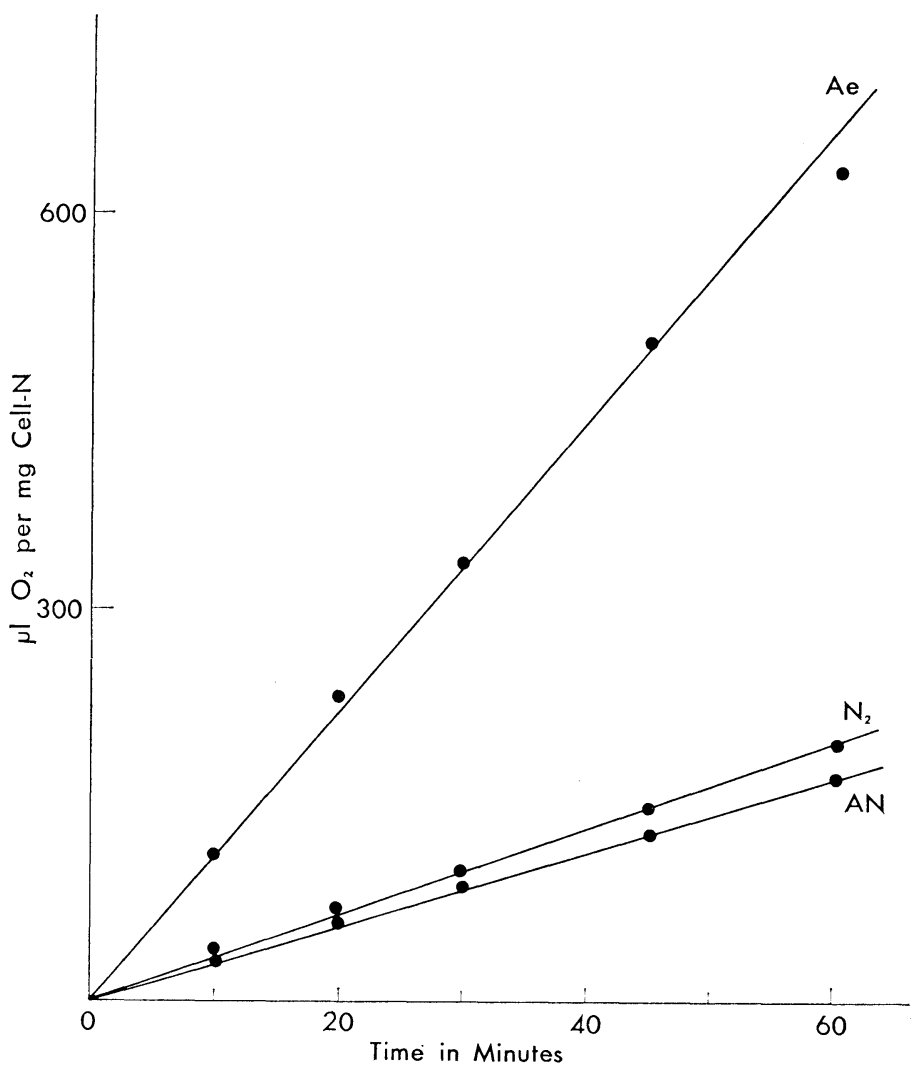

Fig. 4. Aeration and increase of respiratory activity of cells grown in the absence of glucose.

Cells grown anaerobically in glucose-free medium were suspended in a buffer containing $2 \%$ casamino acids and shaken in air or nitrogen for $2.5 \mathrm{hr}$. Optical density of the cell suspension measured after 1:5 dilution: at $0 \mathrm{hr}, 0.350$; after $2.5 \mathrm{hr}$ in air, 0.355 ; after $2.5 \mathrm{hr}$ in nitrogen, 0.355. Respiratory activity on succinate was measured before (AN) and after cells were shaken in air $(\mathrm{Ae})$ or nitrogen $\left(\mathrm{N}_{2}\right)$. In this particular experiment, final substrate concentration was $0.03 \mathrm{M}$. Endogenous respiration subtracted.

(Curve B in Fig. 5) show peaks of cytochrome $b_{1}(560,530,428 \mathrm{~m} \mu)$, cytochrome $a_{2}(630 \mathrm{~m} \mu)$, and a shoulder of cytochrome $a_{1}(590-600 \mathrm{~m} \mu)$. The difference spectra of these aerobic cells (Curves A and B in Fig. 6) similarly show peaks of cytochrome $b_{1}(560,530 \mathrm{~m} \mu)$, cytochrome $a_{2}(630 \mathrm{~m} \mu)$, and a shoulder of cytochrome $a_{1}(590-600 \mathrm{~m} \mu)$. Although the results illustrated in these graphs reveal little difference in cytochrome content between cells grown 


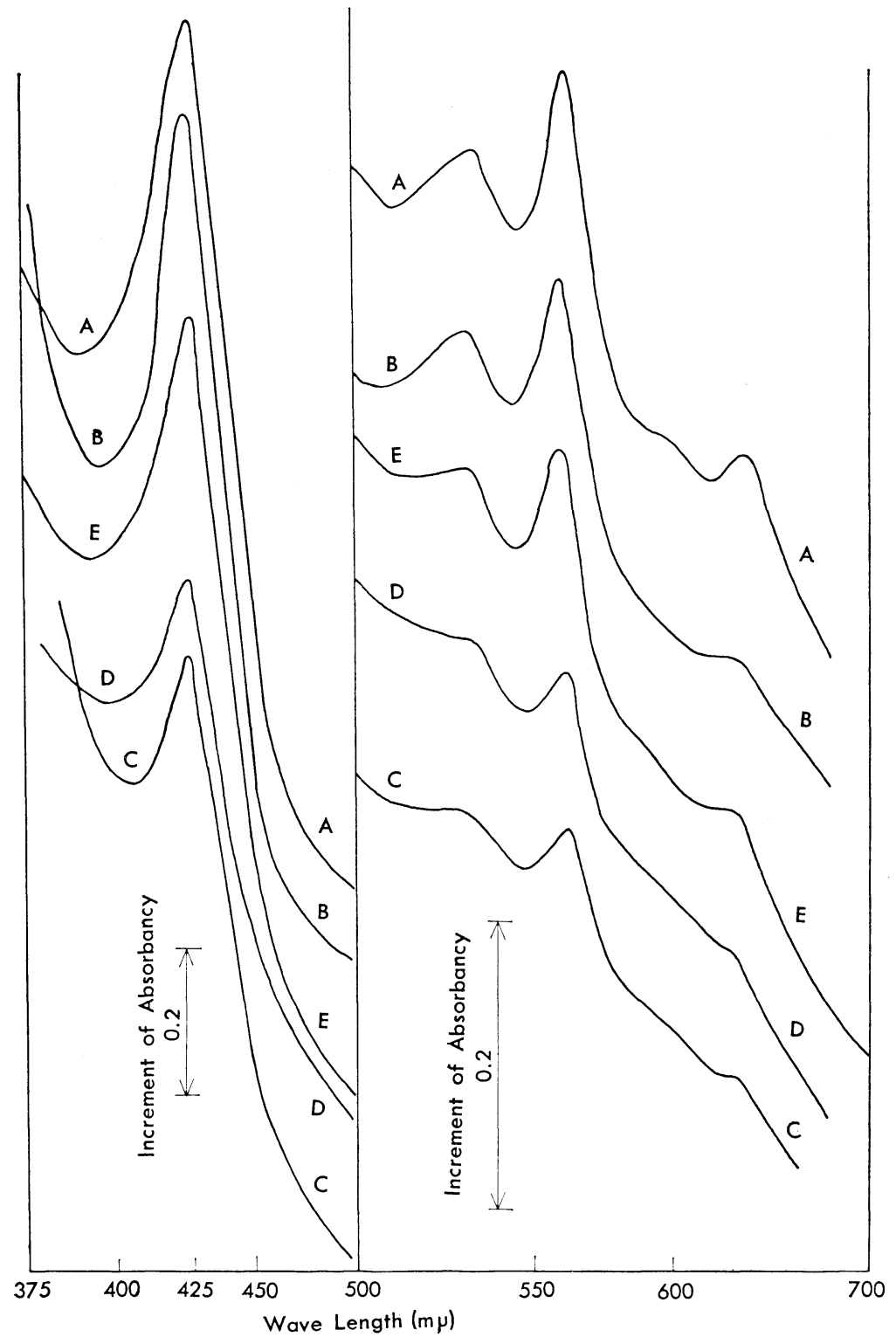

Fig. 5. Reduced cytochrome spectra of intact $E$. coli cells.

Cytochromes were reduced with sodium ascorbate and dithionite. Cell concentrations in optical cuvettes were adjusted to between 2.4 to $2.6 \mathrm{mg}$ cell$\mathrm{N} / \mathrm{ml}$. Curve A, cells grown aerobically in glucose-free medium; B, cells grown aerobically in glucose-containing medium; C, cells grown anaerobically in glucose-containing medium; D, cells obtained after aerating anaerobic cells for $2.5 \mathrm{hr}$ in casamino acids; E, cells obtained after aerating anaerobic cells for $4 \mathrm{hr}$ in casamino acids and beef extract. 


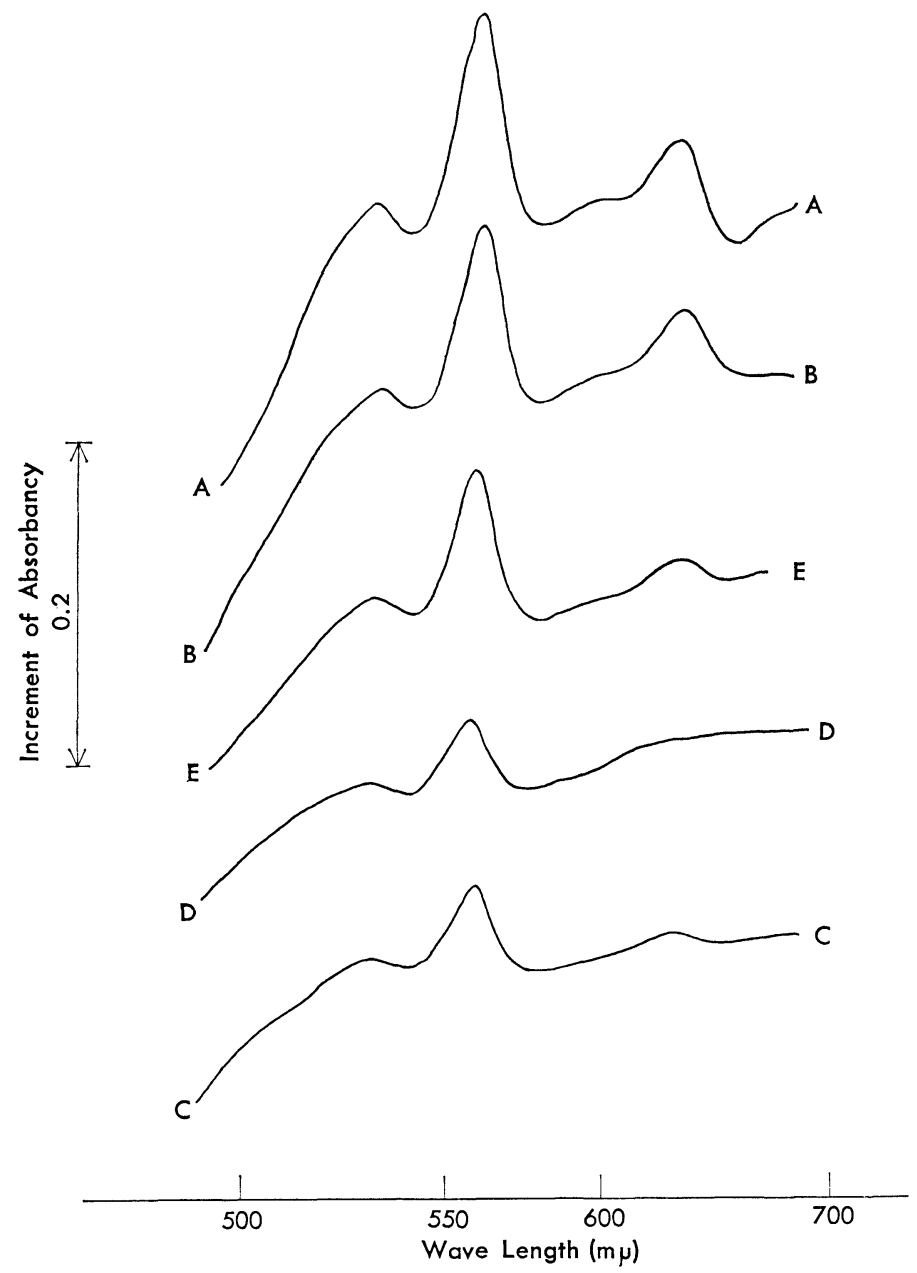

Fig. 6. Reduced minus oxidized difference spectra of $E$. coli cells.

Reduced samples were those used for the measurement of absolute spectra shown in Fig. 5. Oxidized samples were obtained by adding ferricyanide to the remaining cell suspensions after use to obtain reduced samples. For the explanation of each curve, see legend to Fig. 5 .

in the presence and absence of glucose, the content of cytochromes in glucose-grown cells is occasionally lower than in those grown without glucose.

Absorption spectra of anaerobically grown cells (Curve C in Figs. 5 and 6) give different feature from that of aerobically grown cells; the absorptions by cytochrome $b_{1}$ at 560,530 and $428 \mathrm{~m} \mu$ are less intense, and the peak of 
cytochrome $a_{2}$ and the shoulder of cytochrome $a_{1}$ are hardly observed.

The cytochrome spectra of the cells obtained after aerating anaerobic cells for $2.5 \mathrm{hr}$ in a buffer containing $2 \%$ casamino acids are shown by Curve $\mathrm{D}$ in Figs. 5 and 6 . It is a salient feature that the spectra are almost identical between the aerated cells and the unaerated anaerobic cells, because the former cells have much higher respiratory activity than the latter cells. When, however, anaerobic cells were aerated for $4 \mathrm{hr}$ in a buffer containing casamino acids, supplemented with $2 \%$ beef extract and $500 \mathrm{units} / \mathrm{ml}$ of penicillin, the content of cytochrome $b_{1}$ and cytochrome $a_{2}$ definitely increased as shown by Curve $\mathrm{E}$ in Figs. 5 and 6, though there was no significant increase of cell number or cell nitrogen during the aeration.

\section{DISCUSSION}

According to previous workers, respiratory activity of $E$. coli cells grown aerobically was only slightly higher (less than two-fold) than that of cells grown anaerobically (4); while in Bacillus cereus, the reported $\mathrm{Q}_{2}$ values of aerobic and anaerobic cells were 29 and 52, respectively (5). In these experiments, it was shown that oxygen tension during growth had considerable influence on the composition of cytochromes, but the above results led to the conclusion that in these bacteria, unlike in yeast, the oxygen tension has little influence on the cellular respiratory activity. In these previous studies, glucose was the only substrate with which the respiratory activity was examined.

The present result confirmed the previous one in that the respiratory activity of $E$. coli did not show significant difference between aerobic and anaerobic cells when glucose was used as a substrate, but at the same time revealed that the activity differed considerably when other substances, particularly the members of the tricarboxylic acid cycle, were chosen as the substrate. OOHASHI and HiNo (unpublished) showed that, similar to $E$. coli, the respiratory activity of aerobic cells of $B$. cereus was higher than that of anaerobic cells when the respiratory substrate was acetate, malate, or citrate, but not when the substrate was glucose.

Studies on the environmental influence on the activity or composition of respiratory enzymes in bacteria, with possible exception of Pasteurella pestis $(6,9,10)$, have been almost exclusively performed under conditions that accompanied cell multiplication. In the present study, it was shown that in $E$. coli, like in yeast or $P$. pestis, the respiratory activity of anaerobically grown cells can be increased by aerating the cells in the absence of cell proliferation. Under such conditions the amount of cell nitrogen remains almost constant, suggesting that the general synthesis of proteins does not occur. The need of several amino acids and the inhibition caused by amino acid analogs and chloramphenicol strongly suggest that specific synthesis of protein(s), responsible for the respiration of $E$. coli, is occuring during the development of respiratory activity by aeration. It may be added 
that cell-free extracts of aerated cells show much higher activity of several tricarboxylic acid-cycle enzymes than the extracts from the original unaerated E. coli cells (15).

In yeast and several kinds of bacteria, it has been reported that glucose in culture media influences the development of respiratory enzymes. In $E$. coli, TAMIYA et al. (16) observed the effect of glucose on the development of cytochromes, and HALPERN et al. (17) reported the repression of the synthesis of TCA-cycle enzymes by glucose. Almost all of these studies on yeast and bacteria has been the comparative examination of cells grown under different glucose concentrations. In the present study, the effect of glucose on the development of respiratory activity was examined for a relatively short period using resting cells, and the concentration of glucose was determined before and after aeration. Its result showed that glucose at concentrations of $10^{-0.5} \mathrm{M}$ and $10^{-1.5} \mathrm{M}$ showed almost the same incomplete inhibition. Because the coexistence of diverse respiratory chains in $E$. coli has been suggested $(11,18)$, this effect of glucose is tentatively interpreted as the differential inhibition of the formation of two or more respiratory chains.

Moss (4) showed that the content of cytochrome $a_{2}$ and $b_{1}$ in $E$. coli was lower in anaerobically grown than in aerobically grown cells, but SCHAEFFER (5) could not observe the difference in cytochrome content between these two types of cells. The present result coincides with the former result; cytochrome content in anaerobic cells was distinctly lower than that in aerobic cells. In experiments with nonproliferating cell suspension, cytochrome content of anaerobically grown cells could not be increased by aerating the cells in a buffer containing amino acids alone, but was increased if beef extract was further supplemented to the buffer. The discrepancy between observations by Moss and by SCHAEFFER might be due to the fact that they used different culture media.

In the present experiment, after aerating the cells for $2.5 \mathrm{hr}$ in a buffer containing casamino acids, the respiratory activity increased to a level of aerobically grown cells without notable increase in the cytochrome content. Apparently cytochromes are not the limiting factor for overall rate of respiration in $E$. coli, at least under our experimental condition.

The present experiments reveal that there are similarity and some differences between $E$. coli and yeast as to the effect of environmental oxygen tension on the development of respiratory activity. These differences are: (a) the difference of respiratory activity on glucose between aerobically and anaerobically grown cells is remarkable in yeast but not in $E$. coli; (b) external supply of amino acids is obligatorily required by $E$. coli but not by yeast for the development of respiratory activity; (c) in yeast but not in $E$. coli the development of respiratory activity proceeds when respiration is almost completely inhibited; and (d) in yeast but not in $E$. coil the development of respiratory activity is always accompanied by the increase 
of cytochrome content.

The difference (b) may be explained by the possible difference in pool size of internal amino acids between these two organisms. The difference (c) probably originates from the fact that in yeast energy for the synthesis of respiratory enzymes can be obtained by fermentation of glucose (14), while in $E$. coli energy by fermentation is difficult to obtain since glucose has been eliminated from the incubation mixture because of its highly toxic effect. It is at present difficult to interpret why the difference (a) exists or why respiratory activity in glucose does not differ between aerobically and anaerobically grown $E$. coli. The difference (d) could have resulted from some fundamental difference in the mechanism of regulation by oxygen between yeast and $E$. coli, although no further support for this hypothesis is at present available. More extensive works are obviously needed.

\section{SUMMARY}

1) The respiratory activity of aerobically and anaerobically grown cells of Escherichia coli did not show marked difference when the substrate was glucose. The activity of anaerobically grown cells was distinctly lower than that of aerobically grown cells when respiration was measured on formate, acetate, malate, or succinate.

2) When anaerobically grown cells were aerated for $2.5 \mathrm{hr}$ in the absence of cell multiplication, the original low respiratory activity increased to a level of aerobically grown cells.

3) The development of respiratory activity in resting cells occurred only when several amino acids were present in the incubation mixture. The development was inhibited by ethionine, $p$-fluorophenylalanine, chloramphenicol, and glucose. The development was also inhibited by respiratory poisons such as cyanide, azide, carbon monoxide, and nitrophenols at concentrations that inhibited respiration of aerobically grown cells.

4) In aerobically grown cells a considerable amount of cytochromes $a_{2}$ and $b_{1}$, and a slight amount of cytochrome $a_{1}$ were present, while in anaerobically grown cells these cytochromes were present in a remarkably diminished amount. The cytochrome content of anaerobically grown cells did not increase significantly when resting cells were aerated for $2.5 \mathrm{hr}$ in a buffer containing only amino acids, but did increase when aerated for $4 \mathrm{hr}$ in a mixture containing amino acids and beef extract.

This work was supported by a Grant-in-Aid for Scientific Research from the Ministry of Education. 


\section{REFERENCES}

1) O. WARBURG: Biochem. Z., 189, 350 (1927).

2) B. Ephrussi and P. P. Slonimski: Biochim. Biophys. Acta, 6, 256 (1950).

3) H. Yaoi and H. Tamiya: Proc. Imp. Acad. Tokyo, 4, 436 (1928).

4) F. Moss: Austral. J. Exptl. Biol., 30, 531 (1952).

5) P. Schaeffer: Biochim. Biophys. Acta, 9, 261 (1952).

6) E. Englesberg, A. Gibor and J. B. Levy: J. Bacteriol., 68, 146 (1954).

7) N. J. JACoBs and S. F. Contr: J. Bacteriol., 89, 675 (1965).

8) D. H. L. Bishop, K. P. PANdyA and H. K. King: Biochem. J., 83, 606 (1962).

9) E. Englesberg, J. B. Levy and A. Gibor: J. Bacteriol., 68, 178 (1954).

10) E. Englesberg and J. B. Levy: J. Bacteriol., 69, 418 (1955).

11) L. Smith: In The Bacteria, Vol. II, ed. by I. C. Gunsalus and R. Y. Stanier, Academic Press Inc., New York (1961), p. 365.

12) J. Lascelles: Tetrapyrrole Biosynthesis and Its Regulation, W. A. Benjamin, Inc., Amsterdam (1964), p. 94.

13) J. T. PARK and M. J. Johnson: J. Biol. Chem., 181, 149 (1949).

14) P. P. Slonimski: In Proc. 3rd Intern. Congr. Biochem., Brussels 1955, ed. by C. LiÉBECQ, Academic Press Inc., New York (1956), p. 242.

15) S. Hino and Y. TAkAhashi: J. Japan Biochem. Soc., 37, 671 (1965).

16) H. TAMiYa and S. Yamaguchi: Acta Phytochim., 7, 233 (1933).

17) Y. S. Halpern, A. Even-Shoshan and M. Artman: Biochim. Biophys. Acta, 93, 228 (1964).

18) E. R. Kashket and A. F. Brodie: Biochim. Biophys. Acta, 78, 52 (1963). 